\title{
PAWEŁ GACEK
}

Komenda Główna Policji

\section{ISTOTA KONSTRUKCJI PRAWNEJ DELEGOWANIA POLICJANTA DO INNEJ JEDNOSTKI ORGANIZACYJNEJ POLICJI LUB INNEJ MIEJSCOWOŚCI}

\section{ZAGADNIENIA WSTĘPNE}

Zapewnienie bezpieczeństwa i porządku publicznego jest jednym z kluczowych zadań, do których zobligowane jest państwo'. Tworzy ono szereg instrumentów prawnych mających na celu ochronę tego dobra $^{2}$. Państwo zobowiązane jest do tworzenia zarówno instytucji odpowiedzialnych za wykonanie tego zadania, jak również wyposażanie ich (w tym członków tych organizacji) w uprawnienia do skutecznej i efektywnej realizacji nałożonych na nie obowiązków. Jedną z takich organizacji jest Policja ${ }^{3}$. Jak wynika wprost $\mathrm{z}$ treści art. 1 ust. 1 ustawy

1 S. Pieprzny, Zmiany prawno - organizacyjne w Policji w latach 1990-2007, [w:] Policja w Polsce. Stan obecny i perspektywy, I, red. A. Szymaniak, W. Ciepiela, Poznań 2007, s. 95. Należy bowiem zaznaczyć, że wśród wielu funkcji realizowanych przez państwo jest funkcja obronna, która obejmuje swoim zakresem powinność państwa w sferze zapewnienia bezpieczeństwa i porządku publicznego, por. K. SŁAwıK, Zarys prawa policyjnego, Warszawa 2011, s. 17.

2 Szerzej na ten temat S. Pieprzny, Administracja bezpieczeństwa i porządku publicznego, Rzeszów 2012, s. 68 i n.

3 Jest to podstawowa formacja przeznaczona do ochrony bezpieczeństwa ludzi oraz utrzymania bezpieczeństwa i porządku publicznego. Por. J. Starościak, Prawo 
z 6 kwietnia 1990 r. o Policji ${ }^{4}$ jest ona umundurowaną i uzbrojoną formacją ${ }^{5}$ słuzącą społeczeństwu i przeznaczoną do ochrony bezpieczeństwa ludzi oraz do utrzymywania bezpieczeństwa i porządku publicznego ${ }^{6}$. $\mathrm{Z}$ treści powołanego przepisu wynika zatem, że Policja jest formacją spełniającą rolę służebną w stosunku do społeczeństwa7. Treść art. 1 ust. 1 ustawy o Policji ramowo określa obowiązki Policji, które ta ma wobec społeczeństwa. Ich uszczegółowienie znalazło swoje odzwierciedlenie w art. 1 ust. 2 ustawy o Policji. Należy jednak dodać, że mowa tutaj wyłącznie o podstawowych zadaniach tej formacji ${ }^{8}$. Podany katalog zadań ma jedynie charakter przykładowej egzemplifikacji. Nie jest

administracyjne, Warszawa 1975, s. 537; E. Olejniczak-SzaŁowska, [w:] Prawo administracyjne materialne. Pojęcia, instytucje, zasady, red. Z. Duniewska, B. JaworSKA-DęBsKa, M. Stahl, Warszawa 2014, s. 662, a także J. Starościak, E. Iserzon, Prawo administracyjne $w$ zarysie, Warszawa 1959, s. 386 - w odniesieniu do Milicji Obywatelskiej.

4 Ustawa z 6 kwietnia 1990 r. o Policji (tekst jedn. Dz.U. z 2020 r., poz. 360 ze zm.) dalej: ustawa o Policji.

Przyjęty model Policji, jako organizacji zmilitaryzowanej (paramilitarnej), to jest umundurowanej i uzbrojonej, wynika wprost $\mathrm{z}$ charakteru jej zadań. por. J.P. TARNo, Policja jako organ administracji o kompetencjach szczególnych, [w:] Policja w strukturach administracji publicznej, red. A. BABIŃski, P. Bogdalski, Szczytno 2005, s. 9.

6 „Do celów działania Policji należy zapewnienie bezpieczeństwa ludzi, a także szeroko pojmowanego bezpieczeństwa i porządku publicznego" (W. MACIEJKo, Osobowe prawo administracyjne, Warszawa 2008, s. 149; W. MACIEJKO, M. RoJEWsKI, A. SuŁaw ко-Karetкo, Postępowanie administracyjne. Zarys wykładu części szczególnej, Warszawa 2011, s. 133). Jak dodaje B. Opalıński i P. Szustakiewicz, Policja. Studium administracyjnoprawne, Warszawa 2013, s. 91, jest to nadrzędne zadanie tej formacji.

7 Służebna rola tej formacji była podstawowym celem zmiany jej modelu, która została dokonana w związku z przeobrażeniem się organizacji Milicji Obywatelskiej w Policję (L. Szreder, Policja od 1990 r. w służbie dla obywatela, [w:] Historia i rola społeczna formacji policyjnych w jubileuszu 85-lecia. Materiały z sympozjum naukowego zorganizowanego przez Komendę Główną Policji i Uniwersytet Warszawski - 23 lipca 2004 r. Warszawa 2005, s. 115). Cel ten jest na tyle istotny, że został wpisany jako jedno $\mathrm{z}$ ustawowych zadań, do realizacji których zobowiązana jest Policja.

8 W. Maciejko, Osobowe..., s. 149; W. Maciejko, M. Rojewski, A. SuŁawko-Karetko, Postępowanie..., s. 133; Z. Piątek, R. Socha, P. WArs, [w:] Współczesny wymiar funkcjonowania Policji, red. B. Wiśniewski, Z. Piątek, Warszawa 2009, s. 29 i n. 
zatem katalogiem zamkniętym (numerus clausus) ${ }^{9}$. Może on zatem ulegać pewnym modyfikacjom, w miarę zmian i przeobrażeń w różnych sferach, w tym w szczególności w sferze społeczno - gospodarczej. Policja jest formacją, która musi być na tyle elastyczną organizacją, aby dostosować swoje struktury do szybkiego i efektywnego wykonywania zadań w nowo pojawiających się obszarach lub dziedzinach życia spolecznego ${ }^{10}$. Tam bowiem gdzie pojawia się pewna aktywność ludzka, tam konieczne jest zapewnienie bezpieczeństwa jej uczestnikom. Nie ulega wątpliwości, że wraz z rozwojem technologii i różnych form aktywności człowieka w przestrzeni społecznej, pojawiają się również zagrożenia, w tym w szczególności związane z przestępczością i innymi formami patologii społecznej. Policja musi rozpoznawać określone zjawiska

9 „Zadania wskazane w ustawie o Policji ustawodawca określił jako podstawowe” (R. SzaŁowski, Prawnoadministracyjne kompetencje Policji, Łódź 2010, s. 30), „Z ustawy tej wynika, że podstawowe zadania Policji sprowadzają się wprawdzie do „rozpoznawania, zapobiegania i wykrywania przestępstw i wykroczeń” (funkcja kryminalna; por. art. 14 ust. 1), spełnia ona wiele zadań typu administracyjnego. Kompetencje w zakresie pełnienia zadań administracji publicznej wynikają głównie z poszczególnych ustaw materialnego prawa administracyjnego, ale nie tylko z tego rodzaju norm” (Z. Leoński, Prawo administracyjne, Warszawa 2000, s. 174), „Policja wykonuje swoje zadania w różnych prawnych formach, nie tylko na podstawie ustawy o Policji, ale także dziesiątków innych aktów normatywnych” (E. URA, E. URA, Prawo administracyjne, Warszawa 2004, s. 388), w tym samym tonie E. URA, [w:] Prawo administracyjne, red. E. URA, Rzeszów 1997, s. 361. A. Misıuk dodaje, że katalog zadań Policji ma charakter otwarty. Wiele zadań tej formacji wynika z przepisów szczególnych (A. Misıuk, Instytucje bezpieczeństwa wewnętrznego w Polsce. Zarys dziejów (od X wieku do współczesności), Szczytno 2012, s. 359, Idem, Model Policji w Polsce w latach transformacji systemowej po 1990 roku, [w:] Policja w Polsce. Stan obecny i perspektywy, I, Poznań 2007, s. 57). Ustawodawca może zatem nakładać na Policję także inne zadania i wyposażać ją w inne kompetencje, niż te które wynikają wprost z ustawy o Policji, jednak zadań i kompetencji tych nie można domniemywać - muszą mieć swoje oparcie w przepisach prawa (M. Czury , [w:] Prawo policyjne, red. M. Czuryk, M. Karpiuk, J. Kostrubiec, K. Orzeszyna, Warszawa 2014, s. 55).

10 „Skuteczność działań Policji zależy w dużym stopniu od sprawnie funkcjonujących struktur, zdolnych do szybkiego reagowania i natychmiastowego przeciwdziałania w obliczu nowo powstałych zagrożeń bezpieczeństwa publicznego, struktur bardziej elastycznych w przystosowaniu się do nowej rzeczywistości” (A. Misıuk, Instytucje..., s. 365). 
społeczne, a także być gotowa na podjęcie działań w tych obszarach, w celu ochrony członków społeczeństwa przed pojawiającymi się zagrożeniami. Bezsprzecznie bowiem na Policji, jako największej tego typu formacji, ciąży obowiązek realizacji tego zadania ${ }^{11}$. Działalność innych organizacji, w tym służb, inspekcji i straży ma jedynie charakter uzupełniający w stosunku do zadań Policji ${ }^{12}$. Zgodzić się zatem należy ze stanowiskiem J. Dobkowskiego, który stwierdza, że zajmuje się ona wszystkimi lub prawie wszystkimi sprawami z dziedziny bezpieczeństwa i porządku publicznego ${ }^{13}$.

Możliwość skutecznej i efektywnej realizacji przez Policję powieżonych jej zadań zdeterminowała ustawodawcę do wprowadzenia do ustawy o Policji mechanizmów umożliwiających elastyczną fluktuację kadr, która stanowić ma gwarancję zapewnienia odpowiedniej ilości funkcjonariuszy tam gdzie wymga tego dobro służby. Jedną z instytucji umożliwiających taką fluktuację jest konstrukcja delegowania policjanta, o której mowa w art. 36 ust. 1 - 3 ustawy o Policji. Zatem w dalszej części niniejszego opracowania uwaga zostanie skoncentrowana na szczegółowej analizie regulacji prawnej wynikającej z art. 36 ust. 1 - 3 ustawy o Policji. Konieczne będzie w szczególności wskazanie charakteru prawnego delegowania, podmiotów uprawnionych do dokonania tej czynności oraz zakresu tej instytucji.

11 Jest formacją wiodącą w utrzymaniu bezpieczeństwa i porządku publicznego i ma specyficzną pozycję w systemie organów administracji publicznej (M. RóG, A. SĘK, Materialno - administracyjne aspekty pracy Policji, Pułtusk-Warszawa 2015, s. 11), a także K. SŁAwıк, Zarys..., s. 42; A. Przemyski, M. Róg, Przyszłość ustawy o Policji. Rozważania o możliwych kierunkach zmian w prawie policyjnym, [w:] Policja w Polsce. Stan obecny i perspektywy, I, red. A. Szymaniak, W. Ciepiela, Poznań 2007, s. 127.

12 „Obok Policji, przewidziane ustawą o Policji cele i zadania realizują - w ograniczonym zakresie - również inne organy administracji publicznej” (W. MACIEJKo, Osobowe..., s. 149; W. Maciejko, M. Rojewski, A. SuŁawko-Karetko, Postępowanie..., s. 134).

13 J. Doвкоwsкi, Administracja bezpieczeństwa i porządku publicznego, [w:] Wybrane zagadnienia administracyjnego prawa materialnego, red. W. BEDNAREK, Olsztyn 2000, s. 139. 


\section{STOSUNEK SŁUŻBOWY JAKO INSTRUMENT UMOŻLIWIAJĄCY REALIZACJE ZADAŃ POLICJI}

Funkcjonowanie Policji zależne jest jednak od posiadanego zasobu kadrowego. To policjanci jako członkowie tej organizacji zobowiązani są do wykonywania przydzielonych im zadań, których suma, w szerszym aspekcie, stanowi o stopniu realizacji ustawowych zadań Policji. Zasadne jest zatem stwierdzenie, że o skuteczności i efektywności ich realizacji decyduje prawidłowe i efektywne wykonywanie zadań przez policjantów. Nie jest jednak wystarczającym wyposażenie funkcjonariuszy w uprawnienia do podejmowania działań realizujących zadania Policji. Konieczne jest również wskazanie podstawy zatrudnienia, bowiem stanowi ona więź prawną łączącą osobę fizyczną z formacją. Stanowi ona podstawę wzajemnych uprawnień oraz obowiązków tych podmiotów. Jest jednocześnie środowiskiem, w którym funkcjonuje policjant. Celem Policji jest skuteczne i efektywne realizowanie jej zadań. Zatem każda instytucja ustanowiona w pragmatyce służbowej musi być zdatnym instrumentem prawnym umożliwiającym realizację tego celu. Nie chodzi przy tym wyłącznie o uprawnienia funkcjonariuszy do podejmowania działań w wyniku których możliwe jest zapewnienie, a następnie utrzymanie bezpieczeństwa i porządku publicznego, choć niewątpliwie to one w głównej mierze pozwalają na dążenie do realnego urzeczywistnienia tego celu. Konieczne stało się również uregulowanie we właściwy sposób stosunku służbowego, bowiem stanowi on bazę, która wytycza granicę praw i obowiązków funkcjonariusza, jego powinności wobec organizacji, a także wobec społeczeństwa, a tym samym jego status jako członka formacji policyjnej.

Ustawodawca przyjął, że stosunek służbowy ma charakter wyłącznie administracyjnoprawny ${ }^{14}$, z czego wynika, że jego kształt nie jest, jak

14 P. GACEK, Nawiązanie stosunku służbowego z funkcjonariuszem Policji, „Administracja Teoria Dydaktyka Praktyka” 23.2/2011, s. 76 i n.; IDEM, Odwołanie od rozkazu personalnego, „Przegląd Policyjny” 123.3/2016, s. 80; T. Hanausek, A. Abramkski, J. Leśniewski, S. Pikulski, S. Sagan, M. Taniewska, Prawo Policyjne. Komentarz, Katowice 1992, s. 69; J. KACPRZAK, Stosunki służbowe w formacjach zmilitaryzowanych - charakter prawny, ochrona sądowa, „Przegląd Policyjny” 33.1/1994, s. 97; M. Liwo, 
w przypadku stosunku pracy kształtowany wskutek zgodnych oświadczeń woli dwóch stron, ale w całości przez organ administracyjny (przełożonego właściwego w sprawach osobowych), który w sposób władczy i jednostronny ustala te warunki ${ }^{15}$. Oczywiście nie budzi wątpliwości, że nie dokonuje tego w sposób dowolny, bo jest on determinowany (ograniczony) odpowiednimi przepisami pragmatyki służbowej. Należy jednak zaznaczyć, że wola organu nie może zastąpić zgody osoby

Status służb mundurowych i funkcjonariuszy w nich zatrudnionych, Warszawa 2013, s. 311 i n.; W. Maciejko, Osobowe..., s. 150; W. Maciejko, A. Korcz-Maciejko, Postępowanie $w$ sprawach osobowych $w$ Policji, Wrocław 2010, s. 20; W. Maciejko, M. Rojewski, A. SuŁaw ko-Karetko, Postępowanie..., s. 139; J. Paśnik, Prawo dyscyplinarne $w$ Polsce, Warszawa 2000, s. 167 - i tam powołane orzecznictwo, Leksykon policyjny, red. W. PŁywaczewski, G. KęDzierska, Szczytno 2001, s. 304; P. Szustakiewicz, Istota stosunku służbowego, [w:] W. MACIEJKo, P. Szusta KIEwICz, Stosunek służbowy $w$ formacjach mundurowych, 2016, Legalis; T. SzAnkin, [w:] Prawo... ; E. URA, E. URA, Prawo..., s. 393. Porównaj także ze stosunkiem służbowym funkcjonariuszy Milicji Obywatelskiej - por. M. Zorska, Komentarze do ustaw z 31 stycznia 1950 r. o stosunku służbowym funkcjonariuszów Milicji Obywatelskiej i z 31 stycznia 1959 r. o zaopatrzeniu emerytalnym funkcjonariuszów Milicji Obywatelskiej i ich rodzin, Warszawa 1960, s. 10. Przeciwnie T. Hanausek, Ustawa o Policji. Komentarz, Kraków 1996, s. 72, który wiąże mianowanie z powstaniem stosunku służbowego, a zarazem stosunku pracy. Jak słusznie zauważa T. ZıELIŃski, Stosunek prawa pracy do prawa administracyjnego, Warszawa 1977, s. 181, stosunki służbowe nie mogą być identyfikowane ze stosunkami pracy na podstawie mianowania. Elementem odróżniającym stosunek służbowy z mianowania od stosunku pracy z mianowania jest pełna dyspozycyjność funkcjonariusza. Jest to jednocześnie kryterium odgraniczające te dwa typy stosunków prawnych. Nasilenie pierwiastków władczych w stosunku służbowym jest tak wielkie, że reżim prawa pracy musi ustąpić reżimowi prawa administracyjnego. Szerzej na temat stosunku służbowego - Por. T. Kuczyński, E. Mazurczak-Jasińska, J. Stelina, Stosunek służbowy, [w:] System prawa administracyjnego, XI, red. R. HAUser, Z. NiewiAdomski, A. Wróbel, Warszawa 2011, P. Szustakiewicz, Stosunki służbowe funkcjonariuszy służb mundurowych i żołnierzy zawodowych jako sprawa administracyjna, Warszawa 2012; M. WieczOREK, Charakter prawny stosunków służbowych funkcjonariuszy służb mundurowych, Toruń 2017.

15 „Stosunek służbowy policjanta ma charakter administracyjnoprawny i w związku z tym przełożony, w sprawach osobowych, jednostronnie i władczo kształtuje jego istotne składniki” (wyrok NSA z 28 lutego 2019 r., I OSK 950/17, «Legalis» nr 1940424) w tym samym tonie wyrok WSA w Warszawie z 26 stycznia 2017 r., II SA/Wa 1457/16, «Legalis» nr 1722135. 
fizycznej na poddanie się tym warunkom. Organ administracyjny może bowiem egzekwować prawa i obowiązki wobec funkcjonariusza Policji wynikające z tego stosunku, wyłącznie jeśli uprzednio wyrazi on gotowość (zgodę) na dobrowolne poddanie się tym regułom. Zgoda ta ma kluczowe znaczenie zarówno dla powstania, kontynuowania, jak i rozwiązania stosunku służbowego ${ }^{16}$. Zgodnie bowiem z treścią art. 28 ust. 1 ustawy o Policji stosunek służbowy może być zawiązany jedynie po uprzednim dobrowolnym zgłoszeniu się kandydata do służby w Policji, natomiast organ zobowiązany jest do zwolnienia policjanta, po złożeniu przez niego pisemnego zgłoszenia o wystąpieniu ze służby (art. 41 ust. 3 ustawy o Policji). Tak więc wola osoby fizycznej ma znaczenie wyłącznie w kwestiach zasadniczych, tj. nawiązania, kontynuowania i rozwiązania stosunku służbowego. Nie ma natomiast, co do zasady, znaczenia w aspekcie kształtowania warunków pełnionej służby ${ }^{17}$. Przyjęte przez ustawodawcę rozwiązanie, w odniesieniu do kształtu stosunku służbowego, jest o tyle zasadne, że jak wcześniej wspomniano, każda instytucja pragmatyki służbowej musi stanowić odpowiedni instrument służący realizacji ustawowych zadań Policji. O ile pracodawca może samodzielnie i w granicach dopuszczalnych przez prawo określać (a także modyfikować) cel zatrudnienia pracownika, o tyle podmiot zatrudniający, tj. przełożony właściwy w sprawach osobowych, ogra-

16 „Od woli osoby podejmującej służbę w Policji zależą tylko dwa elementy stosunku służbowego: wstąpienie do służby i wystąpienie ze służby - choć ten ostatni element doznaje pewnych ograniczeń” (B. Opaliński, P. Szustakiewicz, Policja..., s. 133).

17 „Policja stanowi umundurowaną i uzbrojoną formację służącą społeczeństwu i przeznaczoną do ochrony bezpieczeństwa ludzi oraz utrzymania bezpieczeństwa oraz porządku publicznego. Jej hierarchiczność i dyspozycyjność, jako immanentne cechy tej służby służą wykonaniu nałożonych na tę formację zadań i z tego też powodu obowiązujące w niej zasady zdyscyplinowania różnią się zasadniczo od innych grup zawodowych. Innymi słowy mówiąc, służba w Policji charakteryzuje się stosunkiem administracyjnoprawnym i w związku z powyższym, to na przełożonym spoczywa obowiązek jednostronnego i władczego kształtowania tzw. polityki kadrowej. Konsensusu w służbie wymaga się jedynie (co do zasady) przy przyjęciu do służby w Policji, a nie do ustalania warunków jej pełnienia" (wyrok WSA w Warszawie z 24 października 2012 r., II SA/Wa 1210/12, «Legalis» nr 554973). Funkcjonariusz nie może zatem negocjować z przełożonym warunków służby (B. Opaliński, P. Szustakiewicz, Policja..., s. 133). 
niczony jest przepisami ustawy o Policji, które wytyczają obszar, sferę czy zakres spraw zastrzeżonych dla Policji. Zatem przepisy te wskazują również na cel zatrudnienia funkcjonariuszy. Zatrudnienie policjantów podporządkowane jest temu celowi. Podstawa zatrudnienia musi zatem w sposób jak najbardziej pełny umożliwiać jednostkom wykonywanie przydzielonych im zadań, których suma zmierza do wypełnienia zadań całej formacji. Przyjęcie odmiennego stanowiska nie wytrzymuje krytyki. Mogłoby to bowiem utrudnić lub też uniemożliwić realizację celu, dla którego organizacja ta została powołana do życia.

Charakterystycznymi cechami stosunku służbowego jest wzmożona dyspozycyjność ${ }^{18}$ funkcjonariusza co do miejsca, czasu oraz rodzaju wykonywanych czynności służbowych, zwiększony stopień podporządkowania wobec jego przełożonych (w tym wobec bezpośredniego przełożonego, przełożonego właściwego w sprawach osobowych, etc. $)^{19}$ oraz korelująca $\mathrm{z}$ wymienionymi obowiązkami zwiększona odpowiedzialność o charakterze dyscyplinarnym i porządkowym ${ }^{20}$. Każdy

18 „(..) istotą służby w Policji jest m.in. dyspozycyjność jej funkcjonariuszy, a granice dyspozycyjności zakreślone są przepisami ustawy oraz aktów wykonawczych" (wyrok NSA z 28 lutego 2019 r., I OSK 950/17...), w tym samym tonie wyrok WSA w Warszawie z 26 stycznia 2017 r., II SA/Wa 1457/16..., „Służba w Policji jest szczególnym rodzajem służby publicznej podlegającej określonym rygorom i ograniczeniom, a warunkiem jej pełnienia jest dyspozycyjność, która polega na poddaniu się szczególnej dyscyplinie służbowej” (wyrok WSA w Krakowie z 23 sierpnia 2012 r., III SA/Kr 1483/11, «Legalis» nr 866455).

19 Zobowiązujący do wykonywania rozkazów i poleceń wydawanych przez tych przełożonych. Jak słusznie zaznacza B. Opalıńki, P. Szustakiewicz, Policja..., s. 141 i n. obowiązek ten ma charakter bezwzględny, co oznacza, że policjant, co do zasady, nie może ich kwestionować, chyba, że zachodzi przypadek wskazany w art. 58 ust. 2 ustawy o Policji. Regułą jest zatem to, iż charakter służby, jej hierarchiczność powoduje, że nie ma w niej miejsca na „dyskusję”.

20 „Akt mianowania powoduje nawiązanie stosunku służby w Policji. Jednym ze skutków nawiązania stosunku służby jest powstanie po stronie przełożonego służbowego policjanta daleko posuniętego władztwa administracyjnego - władztwa służbowego. Treścią władztwa służbowego jest, zabezpieczony sankcją dyscyplinarną, tytuł przełożonego służbowego do wiążącego wydawania podwładnemu rozkazów oraz poleceń służbowych" (W. Maciejko, Osobowe..., s. 156, W. Maciejko, M. Rojewski, A. SuŁawko-Karetko, Postępowanie..., s. 141). Por. z P. Bogdalski, M. Świderski, 
policjant zobowiązany jest bowiem do zachowania dyscypliny służbowej ${ }^{21}$, jaka obowiązuje w organizacji posiadającej strukturę zhierarchizowanąa ${ }^{22}$. Jak podkreśla doktryna, wstąpienie do służby oznacza, że funkcjonariusz zobligowany jest do poddania się szczególnego rodzaju reżimowi związanemu z wykonywaniem służby. Obowiązki policjanta wynikają $\mathrm{z}$ kolei $\mathrm{z}$ charakteru zadań nałożonych przez ustawodawcę na Policję ${ }^{23}$. Z drugiej jednak strony stosunek ten cechuje jego większa trwałość, w porównaniu $\mathrm{z}$ innego rodzaju stosunkami prawnymi. Może on bowiem zostać rozwiązany wyłącznie na jednej z podstaw zwolnieniowych wskazanych w ustawie o Policji. Przełożony właściwy w sprawach osobowych musi nie tylko wskazać odpowiednią podstawę prawną zwolnienia, ale wykazać, iż zmaterializowała się odpowiednia przesłanka lub przesłanki warunkujące zastosowanie odpowiedniej podstawy zwolnieniowej.

Jednym z przejawów zwiększonej dyspozycyjności funkcjonariusza jest możliwość delegowania go do czasowego pełnienia służby w innej jednostce organizacyjnej Policji lub w innej miejscowości. Instytucja ta została określona w art. 36 ust. 1 - 3 ustawy o Policji. Chociaż wymieniony przepis w ust. 1 stanowi podstawę zarówno do przeniesienia do pełnienia służby, jak i do delegowania do czasowego pełnienia służby

K.A. Wojtaszczy к, Słownik wiedzy o Policji, Warszawa 2015, s. 235 - definiującego służbę w Policji jako - nawiązany w drodze mianowania stosunek prawny polegający na dyspozycyjności i podporządkowaniu policjanta władzy służbowej co do rodzaju pełnionej służby.

${ }^{21}$ „Dyscyplina służbowa to nałożone na policjanta powinności o charakterze ogólnym, zbliżone do obowiązków innych pracowników mianowanych w administracji państwowej oraz powinności o charakterze szczególnym, wynikające z regulacji kształtujących stosunek służbowy w Policji, i o charakterze indywidualnym, związanym z zakresem działania indywidualnie oznaczonego policjanta na konkretnym stanowisku służbowym" (J. PAśnik, Prawo..., s. 174).

22 „Organizacja Policji jako części administracji rządowej jest oparta na zasadzie centralizmu i hierarchicznego podporządkowania" (J.P. Tarno, Policja..., s. 10). Por. zarządzenie nr 30 Komendanta Głównego Policji z 16 grudnia 2013 r. w sprawie funkcjonowania organizacji hierarchicznej w Policji (tekst jedn. Dz. Urz. KGP z 2018 r., poz. 89 ze zm.).

23 B. Opaliński, P. Szustakiewicz, Policja..., s. 140. 
w innej jednostce organizacyjnej Policji lub w innej miejscowości ${ }^{24}$, w dalszej części niniejszego opracowania uwaga zostanie skoncentrowana wyłącznie na problematyce związanej z delegowaniem funkcjonariusza do czasowego pełnienia służby w innej jednostce organizacyjnej Policji lub w innej miejscowości. Konstrukcja, o której mowa nie ulegała zasadniczym zmianom w trakcie obowiązywania ustawy o Policji. Pierwotnie art. 36 ust. 1 ustawy o Policji przewidywał delegowanie do czasowego pełnienia służby w innej miejscowości. Zmiana wprowadzona ustawą z 26 czerwca 2014 r. o zmianie ustawy o Policji oraz niektórych innych ustaw ${ }^{25}$ umożliwiała nie tylko delegowanie do czasowego pełnienia służby w innej miejscowości, ale także w innej jednostce organizacyjnej Policji. Pozostałe zmiany w obrębie art. 36 ust. 2 ustawy o Policji dotyczyły systematycznego rozszerzenia podmiotów upoważnionych do delegowania. Sama jednak konstrukcja prawna tej instytucji w swej istocie nie uległa zasadniczej zmianie (modyfikacji).

Niezbędne zatem w dalszej części będzie omówienie delegowania jako sprawy osobowej policjanta, a także szczegółowa analiza regulacji prawnej wynikająca $\mathrm{z}$ art. 36 ust. 1 - 3 ustawy o Policji, w tym w szczególności wskazanie charakteru prawnego delegowania, podmiotów uprawnionych do dokonania tej czynności oraz zakresu tej instytucji.

24 Nie można w pełni zgodzić się z twierdzeniem, że „Artykuł 36 ustawy o Policji określa dwie instytucje prawne: reguły czasowego przeniesienia lub delegowania funkcjonariusza w ramach Policji (art. 36 ust. 1-3 ustawy o Policji)" (B. Opaliński, M. Rogalski, P. Szustakiewicz, uwagi do art. 36, [w:] Ustawa o Policji. Komentarz, Warszawa 2015, Legalis). Przeniesienie, co do zasady nie jest ograniczone czasowo. Tylko delegowanie ma charakter temporalny, a jego granice wytycza art. 36 ust. 3 ustawy o Policji. Przepis wymieniony jako ostatni nie odnosi się w żadnej mierze do instytucji przeniesienia. Tak więc przepis art. 36 ust. 1-3 ustawy o Policji określa dwie instytucje, tj. przeniesienia do pełnienia służby, a także delegowania do czasowego pełnienia służby w innej jednostce organizacyjnej Policji lub w innej miejscowości.

25 Art. 1 pkt 24 ustawy z 26 czerwca 2014 r. o zmianie ustawy o Policji oraz niektórych innych ustaw (Dz.U. z 2014 r., poz. 1199). 


\section{Delegowanie jako sprawa osobowa}

Zgodnie z $\$ 1$ pkt 4 rozporządzenia Ministra Spraw Wewnętrznych z 14 maja 2013 r. w sprawie szczegółowych praw i obowiązków oraz przebiegu służby policjantów ${ }^{26}$, sprawą osobową jest sprawa związana z nawiązaniem, zmianą i rozwiązaniem stosunku służbowego oraz wynikającymi z jego treści prawami i obowiązkami policjantów. Z kolei $\$ 3$ ust. 1 pkt 1 - 14 zawiera przykładową egzemplifikacje spraw kwalifikowanych jako sprawy osobowe. W punkcie $5 \$ 3$ ust. 1 wymienionego rozporządzenia wprost wskazano delegowanie jako sprawę osobową. Sprawy osobowe załatwiane są w formie rozkazu personalnego, o ile odrębne przepisy nie stanowią inaczej ( $\$ 3$ ust. 3 rozporządzenia z 14 maja 2013 r.).

Jak wynika z treści art. 36 ust. 1 ustawy o Policji, delegowanie może nastąpić zarówno z urzędu, jak i na wniosek zainteresowanego policjanta $^{27}$. W obu przypadkach delegowanie wymaga zachowania drogi służbowej, chociaż w zależności od tego czy będzie ono zainicjowane wnioskiem, czy też nastąpi z urzędu, jego przebieg będzie nieco odmienny. Droga służbowa jest bowiem sformalizowanym kanałem komunikacyjnym umożliwiającym relacje pomiędzy poszczególnymi członkami tej organizacji, którzy usytuowani są na różnych szczeblach hierarchicznej struktury organizacyjnej Policji, tj. pomiędzy przełożonymi i podwładnymi, a także pomiędzy podwładnymi a przełożonymi. Wobec tego jest relacją dwukierunkową w układzie pionowym. Zasadą jest, że policjant składa wniosek w sprawie osobowej z zachowaniem drogi służbowej chyba, że przepis szczególny stanowi inaczej ( $\$ 2$ ust. 1 rozporządzenia z 14 maja 2013 r.). Zatem zainteresowany policjant zobowiązany jest złożyć wniosek w sprawie delegowania do swojego bezpośredniego przełożonego. Wniosek ten ma formę raportu. Przepisy nie

26 Rozporządzenie Ministra Spraw Wewnętrznych z 14 maja 2013 r. w sprawie szczegółowych praw i obowiązków oraz przebiegu służby policjantów (Dz.U. z 2020 r., poz. 113 ze zm.).

A. MichaŁek, [w:] Ł. Czebotar, Z. Gądzik, A. Łyżwa, A. MichaŁek, A. ŚwierCzewska-Gąsiorowska, M. TokArski, Ustawa o Policji. Komentarz, Warszawa 2015, s. 394, wskazuje, że może to nastąpić na „prośbę zainteresowanego”. 
określają elementów, które musi spełniać raport, ale niewątpliwie winien on zawierać dane policjanta, tj. stopień, imię i nazwisko, identyfikator służbowy (ID), stanowisko służbowe, oznaczenie komórki i jednostki organizacyjnej Policji, w której pełni służbę, datę sporządzenia, wskazanie przełożonego do którego jest kierowany, treść, w której zawarty jest wniosek o delegowanie do czasowego pełnienia służby w innej miejscowości lub innej jednostce Policji, a także podpis policjanta. Wskazane również jest aby raport taki zawierał stosowne uzasadnienie. Pragmatyka służbowa nie obliguje do zachowania formy pisemnej raportu w sprawie osobowej, chociaż taka jest najczęściej spotykana. Może to nastąpić także w innej formie, np. za pomocą środków komunikacji elektronicznej. Jeżeli jednak ma formę pisemną, a policjant składa wniosek w sprawie osobowej (raport) osobiście, przyjmujący go potwierdza jego otrzymanie, umieszczając na oryginale i na kopii datę jego otrzymania oraz czytelny podpis ( $\$ 2$ ust. 3 rozporządzenia z 14 maja 2014 r.). Bezpośredni przełożony zobligowany jest do przesłania takiego wniosku wyższemu przełożonemu w terminie 7 dni od dnia jego otrzymania wraz z opinią dotyczącą sposobu jej załatwienia, jeżeli nie jest właściwy do załatwienia tej sprawy. Przepisy nie precyzują jednak, co należy rozumieć pod pojęciem „opinia”, a także nie wskazują w jakiej formie ma być wyrażona. Zazwyczaj przełożony sporządza adnotacje o odpowiedniej treści na raporcie policjanta pod jego treścią albo na odwrotnej stronie. Może też zawrzeć taką opinię w odrębnym dokumencie. Zazwyczaj wskazuje, że zapoznał się z treścią raportu policjanta i przychyla się albo nie do tego wniosku. Może również uzasadnić swoje stanowisko w tej sprawie, lecz nie jest to wymóg obligatoryjny. Przedmiotowy raport jest przekazywany do przełożonego, o którym mowa w art. 36 ust. 2 ustawy o Policji, za pośrednictwem kolejnych przełożonych, którzy również zobowiązani są do wypełnienia obowiązku z $\$ 2$ ust. 2 rozporządzenia z 14 maja 2013 r. O sposobie załatwienia wniosku w sprawie osobowej należy zawiadomić policjanta w terminie 30 dni od dnia jego złożenia, o ile odrębne przepisy nie stanowią inaczej ( $\$ 2$ ust 4 rozporządzenia z 14 maja 2013 r.). W tym terminie policjant winien otrzymać rozkaz personalny o delegowaniu, albo pismo odmawiające takiego delegowania. Oczywiście odpowiedź również przekazywana jest na drodze służbowej 
od przełożonego, o którym mowa w art. 36 ust. 2 ustawy o Policji, do zainteresowanego policjanta, za pośrednictwem kolejnych przełożonych. Dodać również należy, że termin wskazany w przepisie $\$ 2$ ust. 4 rozporządzenia z 14 maja 2013 r. ma jedynie charakter instrukcyjny i jego przekroczenie nie może mieć żadnego wpływu na treść podjętego rozstrzygnięcia w tej sprawie, a także na jego ważność i skuteczność. Może jedynie, w sytuacji ustalenia zawinionego przekroczenia tego terminu, skutkować konsekwencjami natury dyscyplinarnej dla osoby odpowiedzialnej za zaistniałą zwłokę. Z oczywistych względów, jeśli delegowanie następuje $\mathrm{z}$ urzędu, doręczenie rozkazu personalnego $\mathrm{z}$ zachowaniem drogi służbowej ograniczone jest wyłącznie do przekazania tego rozkazu od przełożonego, o którym mowa w art. 36 ust. 2 ustawy o Policji, do policjanta, którego to delegowanie dotyczy, za pośrednictwem kolejnych przełożonych, którzy zobowiązani są jedynie do wykonania czynności materialno - technicznej, polegającej na przekazaniu raportu swoim podwładnym, będącym również przełożonymi w stosunku do policjanta delegowanego, aż do bezpośredniego przełożonego tego policjanta, który doręcza mu ten rozkaz. Przekazywanie takiego rozkazu nie łączy się już z koniecznością wyrażenia przez tych przełożonych opinii, bowiem nie mamy już do czynienia z wnioskiem policjanta, ale $z$ rozkazem personalnym przełożonego. W uzupełnieniu należy jeszcze zaznaczyć, że przed wydaniem rozkazu personalnego o delegowaniu, albo w sytuacji odmowy takiego delegowania (jeśli policjant wystąpił z takim wnioskiem) kierownik komórki organizacyjnej właściwej w sprawach osobowych albo osoba wyznaczona przez przełożonego właściwego w sprawach osobowych przygotowuje sprawy osobowe do załatwienia lub zaopiniowania przez przełożonego właściwego w sprawach osobowych ( $\$ 3$ ust. 2 rozporządzenia z 14 maja 2013 r.). W tym przypadku konieczne jest stwierdzenie, że chodzi o kierownika komórki organizacyjnej właściwej w sprawach osobowych albo osobę wyznaczoną przez przełożonego właściwego w sprawach osobowych, o którym mowa w art. 36 ust. 2 ustawy o Policji, bowiem te podmioty są uprawnione do delegowania policjanta. 


\section{Podmioty upraWnione do Delegowania Policjanta}

Przepis art. 36 ust. 2 ustawy o Policji zawiera katalog zamknięty $(n u-$ meru clausus) podmiotów uprawnionych do delegowania policjanta ${ }^{28}$. Są nimi: Komendant Główny Policji na obszarze całego państwa, Komendant Centralnego Biura Śledczego Policji (CBŚP) w odniesieniu do policjanta CBŚP w ramach tej jednostki organizacyjnej, Komendant Biura Spraw Wewnętrznych Policji (BSWP) w odniesieniu do policjanta BSWP w ramach tej jednostki organizacyjnej, komendant wojewódzki Policji na obszarze właściwego województwa, komendant powiatowy (miejski) Policji na obszarze właściwego powiatu (miasta). Jeżeli przeniesienie między województwami, a także między CBŚP a innymi jednostkami organizacyjnymi Policji oraz między BSWP a innymi jednostkami organizacyjnymi Policji następuje w związku z porozumieniem zainteresowanych przełożonych i policjanta, przeniesienia dokonuje komendant wojewódzki Policji właściwy dla województwa, w którym policjant ma pełnić służbę, w przypadku przeniesienia do CBŚP - Komendant CBŚP, a w przypadku przeniesienia do BSWP - Komendant BSWP29. Jak wy-

28 „Artykuł 36 ust. 2 ustawy o Policji określa przełożonych uprawnionych do przeniesienia funkcjonariusza. Zbiór ten ma charakter zamknięty. Inni przełożeni niewymienieni w przepisie nie mogą wydawać decyzji o przeniesieniu lub delegowaniu" (B. Opaliński, M. Rogalski, P. Szustakiewicz, uwagi do art. 36...

29 Pierwotnie był nim: Komendant Główny Policji na obszarze całego państwa, komendant wojewódzki Policji na obszarze właściwego województwa, komendant rejonowy Policji na obszarze właściwego rejonu - por. ustawa z 6 kwietnia 1990 r. o Policji (Dz.U. z 1990 r. Nr 30, poz. 179). Zmiany art. 36 ust. 2 ustawy o Policji dokonano art. 62 pkt 17 ustawy z 24 lipca 1998 r. o zmianie niektórych ustaw określających kompetencje organów administracji publicznej - w związku z reformą ustrojową państwa (Dz.U. z 1998 r. Nr 106, poz. 668) w brzemieniu: Do przenoszenia lub delegowania policjanta właściwi są: Komendant Główny Policji na obszarze całego państwa, komendant wojewódzki Policji na obszarze właściwego województwa, komendant powiatowy (miejski) Policji na obszarze właściwego powiatu (miasta). Jeżeli przeniesienie między województwami następuje w związku z porozumieniem zainteresowanych przełożonych i policjanta, przeniesienia dokonuje komendant wojewódzki Policji, właściwy dla województwa, w którym policjant ma pełnić służbę. Z kolei art. 1 pkt 24 ustawy z 26 czerwca 2014 r. o zmianie ustawy o Policji oraz niektórych innych ustaw dodano do katalogu podmiotów uprawnionych Komendanta CBŚP. Natomiast art. 4 pkt 24 
nika z powyższego właściwość organu uprawnionego do podejmowania decyzji w tej materii uzależniona jest od jednostki organizacyjnej Policji, w której policjant pełni służbę i od jednostki do której policjant ma być delegowany.

Zauważyć należy, że art. 36 ust. 2 ustawy o Policji przekazuje uprawnienie do delegowania wyłącznie wyszczególnionym w tym przepisie przełożonym właściwym w sprawach osobowych. Działanie z urzędu nie wymaga spełnienia przez nich dodatkowych czynności, poza tymi które wprost wynikają z art. 36 ust. 2 ustawy o Policji (tj. zawarcia porozumienia pomiędzy poszczególnymi przełożonymi, w sytuacjach w tym przepisie wskazanych). Nie przewidziano również współuczestnictwa innych podmiotów (zewnętrznych) w tej procedurze. Uzależnienie decyzji o delegowaniu z urzędu od stanowiska innych podmiotów, niewskazanych w art. 36 ust. 2 ustawy o Policji, w tym w szczególności od stanowiska samego policjanta, którego to dotyczy, naruszyłoby istotę konstrukcji prawnej, o której mowa w art. 36 ustawy o Policji, a tym samym spowodowałoby, iż byłby to instrument prawny nieskuteczny i niezdatny do osiągnięcia zamierzonego celu. W przypadku zatem kolizji między interesem policjanta a interesem służby (dobrem służby), niewątpliwie należy dać prymat dobru wskazanemu jako ostatnie. Realizacja celu dla którego instytucja delegowania została ustanowiona wymaga aby uprawnienie wynikające $\mathrm{z}$ art. 36 ust. 1 ustawy o Policji należało wyłącznie do przełożonego właściwego w sprawach osobowych, o którym mowa w art. 36 ust. 2 ustawy o Policji. Pozostaje ono w wyłącznej dyskrecjonalnej władzy tego przełożonego, który podejmując decyzję o delegowaniu winien kierować się dobrem służby. To on jest bowiem odpowiedzialny za stan bezpieczeństwa i porządku publicznego na obszarze pozostającym w granicach właściwości miejscowej danej jednostki, którą kieruje (a także jednostek jej podległych). On również kształtuje politykę kadrową tej jednostki. Zatem zobowiązany jest do

lit. a) ustawy z 9 listopada 2017 r. o zmianie ustawy o niektórych uprawnieniach pracowników urzędu obsługującego ministra właściwego do spraw wewnętrznych oraz funkcjonariuszy i pracowników urzędów nadzorowanych przez tego ministra oraz niektórych innych ustaw (Dz.U. z 2018 r., poz. 106) dodano do katalogu podmiotów uprawnionych Komendanta BSWP. 
maksymalnego wykorzystania zasobu kadrowego, którym dysponuje, w taki sposób aby możliwym było właściwe i prawidłowe wykonywanie ustawowych zadań Policji. To z kolei determinowało do przyjęcia takiej konstrukcji delegowania, która nie wskazuje precyzyjnych i merytorycznych kryteriów uzasadniających podjęcie decyzji w sprawie delegowania policjanta do innej miejscowości lub innej jednostki organizacyjnej Policji. Przepis ten ma charakter kompetencyjny. Tym samym daje wskazanym przełożonym swobodę $\mathrm{w}$ zakresie rozstrzygania $\mathrm{w}$ tej sprawie, z tym jednak zastrzeżeniem, że musi ona być determinowana celem jakim jest właściwa i prawidłowa realizacja ustawowych zadań Policji.

Delegowanie może nastąpić również na wniosek zainteresowanego policjanta, który zobowiązany jest do złożenia wniosku (raportu) w tej sprawie z zachowaniem drogi służbowej. Nie ma on charakteru wiążącego dla przełożonego, o którym mowa w art. 36 ust. 2 ustawy o Policji. Nie skutkuje tym samym automatycznym delegowaniem go do wskazanej przez niego miejscowości, czy jednostki Policji. Raport policjanta może jedynie zainicjować tę procedurę, nie obliguje natomiast przełożonego do delegowania go. Prymat winien mieć bowiem, w takiej sytuacji, interes służby, nie zaś wyłącznie partykularny interes jednostki. Interes policjanta może być uwzględniony wyłącznie w sytuacji, gdy jest zbieżny $\mathrm{z}$ interesem służby.

\section{Charakter PRAWNy DELegowania}

Jak wskazano wcześniej instytucja delegowania została zaliczona do kategorii spraw osobowych. Te z kolei, co do zasady, rozstrzygane są przez wydanie rozkazu personalnego. Należy zaznaczyć, że rozkazy personalne w określonych kategoriach spraw są decyzjami administracyjnymi w rozumieniu art. 104 ustawy z 14 czerwca 1960 r. kodeks postępowania administracyjnego ${ }^{30}$. Jest tak między innymi w przypadkach nawiązania, zmiany albo rozwiązania stosunku służbowego.

30 Ustawa z 14 czerwca 1960 r. kodeks postępowania administracyjnego (tekst jedn. Dz.U. z 2020 r., poz. 256 ze zm.) dalej: k.p.a. 
Wynika to $\mathrm{z}$ administracyjnoprawnego charakteru stosunku służbowego. Tylko rozkaz personalny, będący jednocześnie decyzją administracyjną, może dokonać zmiany w treści stosunku służbowego, a tym samym jednostronnie i w sposób władczy zmienić warunki pełnionej przez policjanta służby. Delegowanie policjanta do czasowego pełnienia służby w innej miejscowości lub innej jednostce organizacyjnej Policji również następuje przez wydanie rozkazu personalnego, tj. o delegowaniu. W przeciwieństwie do wymienionych wyżej rozkazów personalnych o nawiązaniu, zmianie albo rozwiązaniu stosunku służbowego, rozkaz personalny o delegowaniu nie stanowi decyzji administracyjnej w rozumieniu przepisów k.p.a. ${ }^{31}$. Jest aktem wewnątrz - służbowym ${ }^{32}$, charakteryzującym się podwójną konkretnością. Jest skierowany do indy widualnego adresata, tj. do policjanta, który ma zostać delegowany, a także rozstrzyga konkretną sprawę, tj. o jego delegowaniu. Z uwagi jednak na fakt, że rozkaz personalny o delegowaniu nie jest decyzją administracyjną, jego przedmiot nie statuuje sprawy administracyjnej w rozumieniu art. 1 k.p.a. Instytucja delegowania nie modyfikuje bowiem w żaden sposób istniejącej więzi prawnej pomiędzy policjantem a przełożonym właściwym w sprawach osobowych (podmiotem zatrudniającym). Wskutek delegowania nie następuje mianowanie na nowe (niższe, równorzędne albo wyższe) stanowisko służbowe. Delegowanie nie wpływa również, co do zasady, na zmianę poszczególnych składników uposażenia delegowanego funkcjonariusza. Wobec tego

31 „Rozkaz personalny o czasowym delegowaniu funkcjonariusza do pełnienia służby, wydany na podstawie art. 36 ust. 1 i 2 ustawy z 6 kwietnia 1990 r. o Policji (Dz.U. Nr 30, poz. 179 ze zm.) nie jest decyzją administracyjną w rozumieniu art. 104 k.p.a., od której przysługuje odwołanie do organu wyższej instancji” (wyrok NSA z 29 września 2010 r., I OSK 498/10, «Legalis» nr 553847). W tym samym tonie A. MichaŁEK, [w:] Ustawa..., s. 398.

32 „Czasowe delegowanie funkcjonariusza na podstawie art. 36 ust. 1 i 3 ustawy z 6 kwietnia 1990 r. o Policji (tekst jedn. Dz.U. z 2016 r., poz. 1782 ze zm.) jest aktem władczym o charakterze wewnętrznym, wynikającym z podległości służbowej pracownika" (postanowienie WSA w Gdańsku z 20 kwietnia 2010 r., III SA/Gd 132/10, «Legalis» nr 712681), w tym samym tonie postanowienie WSA w Szczecinie z 27 lutego 2008 r., II SA/Sz 131/08, «Legalis» nr 851105, a także A. МichaєeK, [w:] Ustawa..., s. 398 - i tam powołane orzecznictwo. 
nie przysługuje od niego również żaden środek zaskarżenia w administracyjnym toku instancji ${ }^{33}$. Rozkaz personalny o delegowaniu jest rodzajem polecenia służbowego ${ }^{34}$, służącym realizacji przez przełożonego, o którym mowa w art. 36 ust. 2 ustawy o Policji, władztwa wewnątrz - służbowego, wynikającego z wewnętrznego zorganizowania hierarchicznej struktury organizacyjnej Policji ${ }^{35}$. Rozkaz personalny o delegowaniu zmienia jedynie miejsce lub też jednostkę organizacyjną Policji, w której delegowany policjant zobowiązany jest do czasowego wykonywania czynności służbowych. Nie zmienia natomiast treści istniejącego stosunku służbowego, nie zrywa również istniejącej więzi z przełożonym właściwym w sprawach osobowych. Wskutek zmiany miejsca lub jednostki Policji, w której policjant zobowiązany jest do czasowego świadczenia służby, delegowanie ma wpływ na zmianę jedynie podległości wewnątrz - służbowej, bo zobowiązuje policjanta do podległości wobec nowego bezpośredniego przełożonego, będącego kierownikiem komórki organizacyjnej jednostki Policji, do której

33 „A zatem delegowanie do czasowego pełnienia służby w innej miejscowości jest jedynie aktem władczym o charakterze wewnętrznym, wynikającym z podległości służbowej, niepodlegającym kognicji sądu administracyjnego" (postanowienie WSA w Gdańsku z 20 kwietnia 2010 r., III SA/Gd 132/10...), a także W. Kотоwsкi, Ustawa o Policji. Komentarz, Warszawa 2008, s. 417 - i tam powołany wyrok NSA z 27 kwietnia 2001 r., II SAB 251/00, «Lex» nr 55004.

34 Polecenie służbowe - (zlecenie, rozporządzenie, rozkaz) - nałożenie obowiązku określonego zachowania się policjanta (Leksykon..., red. W. PŁYWACZEWsKi, G. KĘDZIERska, s. 226). Szerzej na ten temat - por. J. ŁęTowski, Polecenie służbowe wadministracji, Warszawa 1972, J. ZIEwıŃski, Rozkaz wojskowy w prawie karnym, Warszawa 1986, s. 40 i n. - który odróżnia rozkazy wojskowe od rozkazów i poleceń wydawanych w organizacjach paramilitarnych (w Milicji Obywatelskiej oraz w Służbie Więziennej). Por. także P. GACEK, Polecenie prokuratora wydane Policji na podstawie art. $15 \$ 1$ k.p.k. (wybrane zagadnienia), „Czasopismo Prawa Karnego i Nauk Penalnych” 4/2018, s. 81 i n., tenże, Niewykonanie rozkazu lub polecenia jako podstawa odpowiedzialności dyscyplinarnej funkcjonariusza Policji, „Policja. Kwartalnik Kadry Kierowniczej Policji” 4/2018, s. 32 i n.

35 „Sprawy wynikające z podległości służbowej dotyczą takich spraw, które związane są z realizacją obowiązków i uprawnień objętych podporządkowaniem (podległością) służbowym w ramach pełnienia służby przez policjanta” (W. Kотоwski, Ustawa..., s. 416). 
policjant został delegowany i w której zobowiązany jest on do czasowego świadczenia służby. Sama natomiast zmiana miejsca pełnionej służby, albo też zmiana zakresu obowiązków, stanowią immanentne elementy stosunku służbowego. Dyspozycyjność policjanta wymaga od niego takiego świadczenia służby jaka jest konieczna dla zapewnienia i ochrony wartości jaką jest dobro służby. Służba wiąże się bowiem immanentnie $\mathrm{z}$ dyspozycyjnością, a ta zobowiązuje do dostosowania się przez funkcjonariusza do nowych potrzeb służby.

Stosunek służbowy, jak wykazano, cechuje zwiększona dyspozycyjność i podporządkowanie funkcjonariusza wobec jego władzy zwierzchniej. Jednym z przejawów owej dyspozycyjności jest uprawnienie do delegowania policjanta do czasowego pełnienia służby w innej miejscowości lub w innej jednostce organizacyjnej Policji. Zatem każdy funkcjonariusz winien być gotowy do świadczenia służby tam gdzie istnieją realne potrzeby służby. Wiedzę natomiast w zakresie wykorzystania umiejętności, doświadczenia i kwalifikacji poszczególnych policjantów, posiadają uprawnieni przełożeni, o których mowa w art. 36 ust. 2 ustawy o Policji, bowiem tylko oni, jako kierownicy jednostek organizacyjnych Policji, posiadają największą wiedzę o potrzebach poszczególnych jednostek i komórek organizacyjnych jednostek Policji im podległych. Podejmując zatem decyzje personalne wobec wskazanych przez siebie policjantów kierują się dobrem służby.

Nie można natomiast uznać by rozkaz personalny o delegowaniu, bądź o jego przedłużeniu stanowił decyzję administracyjną ${ }^{36}$, jak to ma miejsce w przypadku przeniesienia na inne stanowisko służbowe. Nie można bowiem utożsamiać instytucji przeniesienia z delegowaniem. Są one wszak odrębnymi konstrukcjami prawnymi. Przeniesienie zmienia treść stosunku służbowego, w przeciwieństwie od delegowania, które, co również istotne, ma charakter wyłącznie czasowy. Po zakończeniu delegowania policjant wraca do jednostki organizacyjnej Policji lub do miejscowości, w której pełnił służbę przed delegowaniem. Nie wraca

36 „Przedłużenie okresu przeniesienia lub delegowania powinno mieć formę decyzji administracyjnej” (B. Opaliński, M. Rogalski, P. Szustakiewicz, uwagi do art. $36 \ldots$ 
natomiast na „poprzednio zajmowane stanowisko służbowe”, bowiem to nie uległo zmianie wskutek delegowania. Jak słusznie podnosi judykatura „delegowanie do czasowego pełnienia służby na innym stanowisku służbowym w innej miejscowości, w trybie art. 36 ustawy o Policji, nie oznacza jednoczesnego odwołania $z$ dotychczas zajmowanego stanowiska, co wynika z samej istoty delegowania oraz faktu, że powierzenie obowiązków służbowych na innym stanowisku odbywa się w ramach pierwotnego aktu mianowania" ${ }^{37}$.

Delegowanie jest ograniczone czasowo. Zgodnie z art. 36 ust. 3 ustawy o Policji czas delegacji nie może przekraczać 6 miesięcy. Komendant Główny Policji, Komendant CBŚP albo Komendant BSWP w wyjątkowych przypadkach mogą przedłużyć czas delegacji do 12 miesięcy ${ }^{38}$. Okres delegowania może być zatem zmieniony w każdym czasie, nawet przed upływem terminu wskazanego w rozkazie personalnym o delegowaniu. Jest on bowiem, jak wcześniej wskazano, rodzajem polecenia służbowego, a zatem, jak każde polecenie służbowe, może być modyfikowany, bądź zmieniany w sytuacji zmiany okoliczności uzasadniających jego wydanie. Jak wynika z powyższego, przepis art. 36 ust. 3 ustawy o Policji wytycza jedynie maksymalny okres delegowania. Może on naturalnie być krótszy niż 6 miesięcy, bądź po jego przedłużeniu krótszy od 12 miesięcy. Delegowanie ustaje wskutek upływu czasu, o którym mowa w art. 36 ust. 3 ustawy o Policji. Policjant może również zostać odwołany z delegowania przed upływem terminu wskazanego w rozkazie personalnym o delegowaniu, nawet mimo uprzedniego jego przedłużenia. Oczywiście delegowanie ustaje z mocy prawa wskutek rozwiązania stosunku służbowego, bowiem w konsekwencji rozwiązania tej więzi prawnej ustaje również stosunek podległości służbowej policjanta (podwładnego) wobec jego przełożonego.

37 Wyrok WSA w Warszawie z 6 lipca 2006 r., II SA/Wa 697/06, «Legalis» nr 81695, a także W. Koтowsкi, Ustawa..., s. 417 i n.

38 Nie można zatem zgodzić się z twierdzeniem, że „Przepis [art. 36 ust. 3 ustawy o Policji - aut.] wskazuje także okres, na który można przenieść policjanta - wynosi on 6 miesięcy i nie może on przekroczyć roku” (B. Opaliński, M. Rogalski, P. SzUstAKIEWICZ, uwagi do art. 36... Treść tego przepisu dotyczy wyłącznie delegowania. Nieuprawnione byłoby odniesienie go per analogiam do instytucji przeniesienia. 
Dodać również należy, że w sytuacji negatywnego ustosunkowania się przełożonego, o którym mowa w art. 36 ust. 2 ustawy o Policji do wniosku policjanta o delegowanie go do innej jednostki lub innej miejscowości nie jest on zobowiązany do wydawania rozkazu personalnego, a jedynie do poinformowania policjanta drogą służbową o negatywnym stanowisku w tej sprawie ${ }^{39}$. Pismo takie również jest swoistego rodzaju „rozstrzygnięciem”, w znaczeniu negatywnym, które leży w sferze władztwa wewnątrzsłużbowego. Zawiera stanowisko przełożonego właściwego w sprawach osobowych, o którym mowa w art. 36 ust. 2 ustawy o Policji, co do sposobu dalszego zagospodarowania funkcjonariusza. Zatem jest poleceniem służbowym skierowanym do policjanta, który uprzednio wystąpił do tego przełożonego z wnioskiem o delegowanie go do innej jednostki Policji lub do innej miejscowości, którego treść wskazuje, że w uznaniu tego przełożonego zobowiązany jest on do dalszego pełnienia służby (jej świadczenia) w dotychczasowej jednostce organizacyjnej Policji i w miejscowości, z uwagi na aktualne potrzeby służby (dobro służby, albo też interes służby).

\section{ZAKOŃCZENIE}

Konieczność zapewnienia i ochrony bezpieczeństwa i porządku publicznego zdeterminowały ustawodawcę do stworzenia organizacji, tj. Policji, która będzie odpowiedzialna za wykonanie tego zadania. Warunkiem skutecznej realizacji powierzonych tej formacji zadań, było stworzenie (w pragmatyce służbowej) pewnych mechanizmów, które służyć będą tej organizacji w osiągnięciu wymienionego wyżej celu. Jednym z takich instrumentów jest stosunek służbowy. Jak bowiem wcześniej wykazano, Policja jest zdolna do podjęcia i efektywnej realizacji swoich

39 Postanowienie WSA w Warszawie z 27 stycznia 2012 r., II SAB/Wa 414/11, «Legalis» 564937, postanowienie WSA w Rzeszowie z 16 września 2010 r., II SA/Rz 782/10, «Legalis» nr 452376, postanowienie WSA w Szczecinie z 25 marca 2011 r., II SA/Sz 165/11 «Legalis» nr 684267 - co prawda orzeczenia te dotyczą odmowy przeniesienia na inne stanowisko służbowe, jednak per analogiam można je również odnieść do odmownego ustosunkowania się przełożonego do wniosku policjanta o delegowanie. 
zadań wyłącznie za pośrednictwem członków tej formacji, tj. funkcjonariuszy. Stosunek służbowy jest środowiskiem, w którym funkcjonuje policjant, dlatego jego konstrukcja musi być zdatnym instrumentem do zapewnienia najbardziej właściwych warunków umożliwiających prawidłowe i efektywne wykonywanie przez policjanta jego zadań służbowych, których suma, w szerszym aspekcie, jest świadectwem dążenia Policji do realizacji jej ustawowych zadań. Stąd też celowe unormowanie stosunku służbowego, jako stosunku stricte administracyjnoprawnego. Charakterystyczną jego cechą jest wzmożona dyspozycyjności i podporządkowanie policjanta w służbie. Jednym z przejawów zwiększonej dyspozycyjności funkcjonariusza w służbie jest uprawnienie przełożonego właściwego w sprawach osobowych, o którym mowa w art. 36 ust. 2 ustawy o Policji, do delegowania funkcjonariusza do czasowego pełnienia służby w innej jednostce organizacyjnej Policji lub innej miejscowości. Przełożony ten zobligowany jest do kształtowania zasobu kadrowego poszczególnych jednostek Policji w taki sposób, aby umożliwić szybką reakcję na ciągle zmieniające się okoliczności, aby tym samym zapewnić odpowiednią ilość funkcjonariuszy tam gdzie jest to najbardziej niezbędne. Delegowanie policjanta do innej jednostki organizacyjnej Policji lub innej miejscowości jest konstrukcją prawną, która nie powoduje zmian w treści istniejącego stosunku służbowego. Jest swoistego rodzaju poleceniem służbowym, za pomocą którego przełożony właściwy w sprawach osobowych może realizować władztwo wewnątrzsłużbowe. Z uwagi na to, że delegowanie nie zmienia treści stosunku służbowego, decyzja w tej sprawie nie ma formy decyzji administracyjnej, a tym samym policjantowi nie przysługuje żaden środek zaskarżenia w administracyjnym toku instancji na rozkaz personalny o delegowaniu. Policjant nie ma również roszczenia o delegowanie go do innej jednostki organizacyjnej Policji lub innej miejscowości. Delegowanie wymaga bowiem uwzględnienia dobra służby. Interes służby, lub w szerszym znaczeniu interes społeczny, winien mieć prymat przed partykularnym interesem jednostki (policjanta). Zatem delegowanie winno być uzasadnione realnymi potrzebami służby, które wystąpiły w danym czasie. Istotne jest również to, że delegowanie jest ograniczone czasowo. 
Z tego co zostało wyżej powiedziane, prawidłowe zrozumienie istoty delegowania policjanta wymaga usytuowania tej konstrukcji w środowisku stosunku służbowego. Ten z kolei musi stwarzać optymalne warunki do właściwej realizacji ustawowych zadań Policji. Zatem delegowanie musi być również determinowane tym celem - musi być zdatnym instrumentem umożliwiającym realizację tego celu.

Obecny kształt regulacji tej instytucji należy ocenić pozytywnie, bowiem instrument ten pozwala na szybką reakcję przełożonego właściwego w sprawach osobowych, o którym mowa w art. 36 ust. 2 ustawy o Policji, w tych sytuacjach, które wymagają, aby w danej jednostce Policji, lub w danej miejscowości, zwiększyć liczebność funkcjonariuszy, celem prawidłowego, szybkiego, skutecznego i efektywnego wykonania określonych zadań służbowych. Oczywiście instytucja ta może być stosowana tylko w tych przypadkach, gdy jest to konieczne z uwagi na dobro służby. Brak precyzyjnie określonych przesłanek uzasadniających decyzję o delegowaniu może być jednak odczytywane jako istotna wada tej kontrukcji prawnej, bowiem może powodować jej niewłaściwe wykorzystywanie, jako instrumentu represyjnego, który umożliwia czasowe usunięcie funkcjonariusza z danej komórki organizacyjnej lub jednotki Policji, w szczególności w sytuacji konfliktu pomiędzy przełożonym a podwładnym. Nie ulega jednak wątpliwości, że w takich przypadkach należałoby krytycznie odnieść się do przymiotów etyczno-morlanych przełożonego, który instrumentalnie wykorzystuje swoje uprawnienia, aniżeli poszukiwać uzasadnienia do zmiany regulacji zawartej w art. 36 ustawy o Policji.

ISTOTA KONSTRUKCJI PRAWNEJ DELEGOWANIA POLICJANTA DO INNEJ jednostKi ORganizacyjnej Policji lub INNej Miejscowości

\section{Streszczenie}

Niniejszy artykuł w całości został poświęcony omówieniu konstrukcji prawnej delegowania policjanta od czasowego pełnienia służby w innej jednostce Policji lub w innej miejscowości. Instytucja ta została uregulowana w art. 36 ust. 1 - 3 ustawy o Policji. Stosunek służbowy ma 
charakter wyłącznie administracyjnoprawny. Jego charakterystyczną cechą jest zwiększona dyspozycyjność i podporządkowanie policjanta w służbie. Jednym z przejawów tej dyspozycyjności jest możliwość delegowania policjanta. Skoncentrowano zatem uwagę na omówieniu charakteru prawnego tej instytucji oraz podmiotów uprawnionych do jej stosowania.

\section{The Legal Construction of the Delegation of a Police Officer to Another Unit of the Police Force OR TO ANOTHER LOCALITY}

\section{Summary}

This article is a discussion of the legal construction for a police officer's delegation for temporary service in another unit of the police force or in another locality. In Polish law this institution is regulated by Art. 36 (1), (2) and (3) of Ustawa o policji (the Police Act). Polish administrative law gives a definition of the nature of service in the country's police force, and the characteristic feature of police duties it highlights is that the police officer must be fully committed to his/her job and on call for duty whenever required. One of the manifestations of this availability is the fact that he or she may be delegated to another station. This article discusses the legal character of this institution and the entities authorized to use it. 
Słowa kluczowe: policja; policjant; stosunek służbowy; mianowanie; delegowanie; rozkaz personalny.

Keywords: the police; police officer; service in the police force; appointment; delegation; orders issued to the individual.

\section{Bibliografia}

Bogdalski P. red., Policja w strukturach administracji publicznej, Szczytno 2005.

Bogdalski P., Świderski M., Wojtaszczyk K.A., Słownik wiedzy o Policji, Warszawa 2015.

Czebotar Ł., Gądzik Z., Łyżwa A., MichaŁek A., Świerczewska-Gąsiorowska A., Tokarski M., Ustawa o Policji. Komentarz, Warszawa 2015.

Czuryk M., Karpiuk M., Kostrubiec J., Orzeszyna K., red., Prawo policyjne, Warszawa 2014.

Doвкошsкi J., Administracja bezpieczeństwa i porządku publicznego, [w:] Wybrane zagadnienia administracyjnego prawa materialnego, red. W. BEDNAREK, Olsztyn 2000, s. 137-164.

Duniewska Z., Jaworska-DęBSka B., Stahl M., red., Prawo administracyjne materialne. Pojęcia, instytucje, zasady, Warszawa 2014.

GaCeK P., Nawiązanie stosunku służbowego z funkcjonariuszem Policji, «Administracja Teoria Dydaktyka Praktyka» 23.2/2011, s. 68-93.

GACEK P., Niewykonanie rozkazu lub polecenia jako podstawa odpowiedzialności dyscyplinarnej funkcjonariusza Policji, «Policja. Kwartalnik Kadry Kierowniczej Policji» 4/2018, s. 32-47.

GACEK P., Odwołanie od rozkazu personalnego, «Przegląd Policyjny» 123.3/2016, s. 80-98.

GACEK P., Polecenie prokuratora wydane Policji na podstawie art. $15 \$ 1$ k.p.k. (wybrane zagadnienia), «Czasopismo Prawa Karnego i Nauk Penalnych» 4/2018, s. 81-105.

Hanausek T., Abramski A., Leśniewski J., Pikulski S., Sagan S., Taniewska M., Prawo Policyjne. Komentarz, Katowice 1992.

Hanausek T., Ustawa o Policji. Komentarz, Kraków 1996.

KACPRZAK J., Stosunki służbowe w formacjach zmilitaryzowanych - charakter prawny, ochrona sądowa, „Przegląd Policyjny” 33.1/1994, s. 97-111.

Kotowski W., Ustawa o Policji. Komentarz, Warszawa 2008.

Kuczyński T., Mazurczak-Jasińska E., Stelina J., Stosunek służbowy, [w:] System prawa administracyjnego, XI, red. R. Hauser, Z. NiewiadomSKI, A. WróBeL, Warszawa 2011. 
Leoński Z., Prawo administracyjne, Warszawa 2000.

Lıwo M., Status słu̇̇b mundurowych i funkcjonariuszy w nich zatrudnionych, Warszawa 2013.

Łętowski J., Polecenie służbowe w administracji, Warszawa 1972.

MACIEjKo W., Osobowe prawo administracyjne, Warszawa 2008.

Maciejko W., Rojewski M., SuŁawko-Karetro A., Postępowanie administracyjne. Zarys wykładu części szczególnej, Warszawa 2011.

Maciejko W., Korcz-Maciejko A., Postępowanie w sprawach osobowych $w$ Policji, Wrocław 2010.

Misıuk A., Instytucje bezpieczeństwa wewnętrznego w Polsce. Zarys dziejów (od X wieku do wspótczesności), Szczytno 2012.

Misiuk A., Model Policji w Polsce w latach transformacji systemowej po 1990 roku, [w:] Policja w Polsce. Stan obecny i perspektywy, I, Poznań 2007, s. 57-94

Opaliński B., Szustakiewicz P., Policja. Studium administracyjnoprawne, Warszawa 2013.

Opaliński B., Rogalski M., Szustakiewicz P., uwagi do art. 36, [w:] Ustawa o Policji. Komentarz, Warszawa 2015, Legalis.

Paśnik J., Prawo dyscyplinarne w Polsce, Warszawa 2000

Pieprzny S., Administracja bezpieczeństwa i porządku publicznego, Rzeszów 2012

Pieprzny S., Zmiany prawno - organizacyjne w Policji w latach 1990 - 2007, [w:] Policja $w$ Polsce. Stan obecny i perspektywy, I, red. A. Szymaniak, W. Ciepiela Poznań 2007, s. 95-117.

PŁywaczewski W., KęDzierska G., red., Leksykon policyjny, Szczytno 2001. Przemyski A., Róg M., Przyszłość ustawy o Policji. Rozważania o możliwych kierunkach zmian $w$ prawie policyjnym, [w:] Policja $w$ Polsce. Stan obecny i perspektywy, I, red. A. Szymaniak, W. Ciepiela, Poznań 2007, s. 125-134. Róg M., Sє̨K A., Materialno - administracyjne aspekty pracy Policji, PułtuskWarszawa 2015.

SŁAWIK K., Zarys prawa policyjnego, Warszawa 2011.

Starościak J., Prawo administracyjne, Warszawa 1975.

Starościak J., Iserzon E., Prawo administracyjne w zarysie, Warszawa 1959.

SzaŁowski R., Prawnoadministracyjne kompetencje Policji, Łódź 2010.

Szreder L., Policja od 1990 r. w stużbie dla obywatela, [w:] Historia i rola społeczna formacji policyjnych w jubileuszu 85-lecia. Materiały z sympozjum naukowego zorganizowanego przez Komendę Główna Policji i Uniwersytet Warszawski - 23 lipca 2004 r., Warszawa 2005, s. 115-121. 
Szustakiewicz P., Istota stosunku stużbowego, [w:] Maciejko W., SzustaKIEWICZ P., Stosunek stużbowy w formacjach mundurowych, 2016, Legalis. Szustakiewicz P., Stosunki stużbowe funkcjonariuszy stużb mundurowych i żotnierzy zawodowych jako sprawa administracyjna, Warszawa 2012.

TARno J.P., Policja jako organ administracji o kompetencjach szczególnych, [w:] BAbiński A., Bogdalski P., red., Policja $w$ strukturach administracji publicznej, Szczytno 2005, s. 9-12

Ura E., Ura E., Prawo administracyjne, Warszawa 2004.

URA E. red., Prawo administracyjne, Rzeszów 1997.

WieczoreK M., Charakter prawny stosunków służbowych funkcjonariuszy stużb mundurowych, Toruń 2017.

Wiśnıewski B., PiąTek Z., red., Współczesny wymiar funkcjonowania Policji, Warszawa 2009.

ZIELIŃski T., Stosunek prawa pracy do prawa administracyjnego, Warszawa 1977 ZIEwIŃsKi J., Rozkaz wojskowy w prawie karnym, Warszawa 1986.

Zorska M., Komentarze do ustaw z 31 stycznia 1950 r. o stosunku służbowym funkcjonariuszów Milicji Obywatelskiej i z 31 stycznia 1959 r. o zaopatrzeniu emerytalnym funkcjonariuszów Milicji Obywatelskiej i ich rodzin, Warszawa 1960. 